\title{
OBSERVATIONS ON THE NESTING ECOLOGY AND EARLY LIFE HISTORY OF THE DUNES SAGEBRUSH LIZARD (SCELOPORUS ARENICOLUS)
}

\author{
Wade A. Rybergl,2, Michael T. Hill¹, Daniel Lay ${ }^{1}$, and Lee A. Fitzgerald ${ }^{1}$
}

\begin{abstract}
Population studies of the dunes sagebrush lizard (Sceloporus arenicolus) suggest that fluctuations in the population dynamics of this lizard are driven by spatial and temporal variation in annual recruitment. Although variation in survival of eggs or embryos is known to contribute greatly to variation in annual recruitment in many other lizard species, little is known about these early life history stages and their contributions to the population dynamics of S. arenicolus. Here we describe the first 3 observations of nesting in the wild for $S$. arenicolus. All observations took place between 2005 and 2011 at Caprock Wildlife Area, $48 \mathrm{~km}$ east of Roswell, New Mexico. From these observations, we supplement existing knowledge of these early life history stages, which can inform working models of life history evolution for this lizard endemic to the Mescalero Sands and Monahans Sandhills ecosystems.
\end{abstract}

Resumen.-Estudios poblacionales sobre las lagartijas Artemisa de las dunas (Sceloporus arenicolus) sugieren que las fluctuaciones en la dinámica poblacional de esta lagartija se deben a la variación espacial y temporal en el reclutamiento anual. Aunque se conoce que la variación en la supervivencia de huevos o embriones contribuye en gran medida a la variación en el reclutamiento anual en muchas otras especies de lagartijas, poco se sabe sobre estos estadios tempranos de la historia de vida y sus contribuciones a la dinámica poblacional de S. arenicolus. Aquí describimos las primeras tres observaciones de anidaciones en zonas silvestres para S. arenicolus. Todas las observaciones tuvieron lugar entre 2005 y 2011 en el Área Silvestre de Caprock, 48 kilómetros al este de Roswell, en Nuevo México. Con estas observaciones, podemos complementar el conocimiento existente sobre estas etapas tempranas de la historia de vida, que puede utilizarse para documentar los modelos de evolución de la historia de vida de esta lagartija endémica a los ecosistemas arenosos Mescalero y Monahans.

In many lizard populations, variation in survival of eggs or embryos may represent the largest contribution to variation in annual recruitment (Dunham et al. 1988a, Fitzgerald 1994). To understand population fluctuations or factors that affect population dynamics of lizards, it is therefore critical to study factors that influence survival of eggs or embryos (Dunham et al. 1988b). For most oviparous lizards, recruitment can be affected in early life stages by the number of eggs laid and the number of eggs that survive (Fitzgerald 1994, Overall 1994). The number of eggs laid is determined by the age-specific fecundity of the female, which is a product of age-specific energy-allocation decisions that influence the amount of resources available for growth, storage, maintenance, and reproduction (i.e., life history; Dunham et al. 1989). The number of eggs that survive is determined by the biophysical environment, which controls thermal and hydric properties of the nest site during incubation and hatchling development (Tracy and Snell 1985). The selection of the nest site among all biophysical environments available, however, is also a product of female energy-allocation decisions that balance the trade-off between adult female fecundity and survival. Here, we provide the first data on these early life history stages and the nesting ecology of the dunes sagebrush lizard (Sceloporus arenicolus). These data can inform working models of life history evolution for this lizard endemic to the Mescalero Sands and Monahans Sandhills ecosystems in New Mexico and adjacent West Texas (Degenhardt et al. 1996, Fitzgerald and Painter 2009, Laurencio and Fitzgerald 2010).

The earliest information on $S$. arenicolus early life history stages and nesting ecology comes from 2 nesting observations of captive females in 1959 (Sabath 1960). In his note, Sabath (1960) reported that 2 S. arenicolus females from Ward and Winkler counties (Texas) laid 4 and 6 eggs on 20 and 23 June, respectively. These early observations were followed by another nesting observation of a captive female that laid 5 eggs in August 1970 (Degenhardt and Jones 1972). Charles J. Cole (1975)

\footnotetext{
${ }^{1}$ Biodiversity Research and Teaching Collection, Department of Wildlife and Fisheries Sciences, Texas A\&M University, College Station, TX 77843-2258.
} 2E-mail: waryberg@tamu.edu 
reported that a female nested in captivity and laid 4 eggs on 27 June 1973. One of these eggs hatched between 24 and 27 August, an incubation period of 59-62 days. In their examination of the type series, Degenhardt and Jones (1972) also reported a mean clutch size of 5.1 for 12 females. Since the1970s, several surveys, field collections, and research projects studying various aspects of S. arenicolus population biology were conducted throughout the lizard's range (Degenhardt et al. 1996, Smolensky and Fitzgerald 2010, 2011). Those studies and numerous field observations from mark-recapture studies (MTH, LAF, personal observations) demonstrate that $S$. arenicolus vitellogenesis begins by late April, mating occurs from May to early July, and females reproduce once or twice in a season, laying clutches of 3-6 eggs first in June and then again in late July. Hatchlings emerge in mid-July (Degenhardt et al. 1996, Fitzgerald and Painter 2009). Sceloporus arenicolus is also known to migrate out of its normal home range to nest, a behavior known for iguanians, including other species of Sceloporus (Angilletta et al. 2009, Fitzgerald and Painter 2009, Hill and Fitzgerald personal observations). Although the reasons for these nesting movements are probably complex, a useful starting hypothesis is that they reflect nesting female microhabitat selection to ensure egg and hatchling survival. For example, Angilletta et al. (2009) reported that females of other Sceloporus species selected nesting sites that were relatively warm compared to sites typically used in their home ranges.

To begin evaluating the hypothesis that nesting S. arenicolus individuals select nest sites based on biophysical parameters, we report the first 3 descriptions of S. arenicolus nesting in the wild. All observations took place at Caprock Wildlife Area, approximately $48 \mathrm{~km}$ east of Roswell, New Mexico. From late afternoon to early evening on 11 June 2005 and 27 May 2006, 2 different gravid S. arenicolus females $(\mathrm{SVL}=54 \mathrm{~mm}$, mass $=5.7 \mathrm{~g} ; \mathrm{SVL}=$ $53 \mathrm{~mm}$, mass $=5.7 \mathrm{~g}$ ) that were marked with radio-tags dispersed outside their normal home range to adjacent sand dune blowouts or other portions of larger blowout complexes within Shinnery-oak sand dune habitats (for habitat description, see Fitzgerald and Painter 2009). Once the nest site was determined, nest construction began and continued past midnight. In both cases, on the following morning, the nest sites were identified by a loose, moist mound of sand at the entrance of the freshly dug burrow on west-facing, open sandy slopes with sparse vegetation. On 28 May 2006, one of the females was relocated after nesting and weighed $3.9 \mathrm{~g}$, a $31 \%$ reduction in mass. On 15 June 2005 and 29 May 2006, each nest site was excavated by following the burrow down to the nest chamber. The burrows were 11 and $19 \mathrm{~cm}$ long, respectively, and penetrated the sand nearly perpendicular to the surface slope. Both burrows ended at the soil moisture horizon where a nest chamber was constructed measuring $5 \mathrm{~cm}$ and $2 \mathrm{~cm}$ in depth, respectively. Both nests contained 3 eggs packed loosely with moist sand. Soil temperatures adjacent to nests at time of excavation were $25.2{ }^{\circ} \mathrm{C}$ and $25.6{ }^{\circ} \mathrm{C}$. The third lizard nest was unintentionally excavated on 11 July 2011 while we were taking a soil sample at the same study site. The chamber contained 3 eggs buried $20.5 \mathrm{~cm}$ below the soil surface. As described above, the nest was located in a sand dune blowout with little surrounding vegetation. There was no measurable slope or aspect at this location. The nest chamber had collapsed, so no chamber measurements were taken. The eggs were immediately repacked in a soil sample bag containing soil from the original nest chamber and then stored in an insulated beverage cooler. The eggs were transported to the lab on 12 July, where they were incubated at $25{ }^{\circ} \mathrm{C}$. On 4 August, a single S. arenicolus hatching emerged $(\mathrm{SVL}=28.0 \mathrm{~mm}$, tail length $=34.0 \mathrm{~mm}$; TCWC 95591). On 8 August, the remaining 2 eggs were unearthed and inspected. Both eggs were shriveled and moldy with no signs of lizard development.

Because the nest was unearthed at the point of a soil sample, we were presented a unique opportunity to describe selection of a nesting site by S. arenicolus. At the nest location and at 35 other locations assumed to be available to the nesting female (15-78 m from the nest), soil moisture content (\% dry mass basis $=\mathrm{g}$ water/g soil) of samples collected $20 \mathrm{~cm}$ below the surface was measured using the gravimetric method (Carter 1993). Using sand sieve analysis (sieve numbers 45, 60, 100; Folk 1980), sand grain size distribution (\% of total sample mass by grain size class) was also quantified for each sample collected at the soil surface.

Percent soil moisture across all 36 samples ranged from $0.2 \%$ to $7.8 \%$ with a mean of 

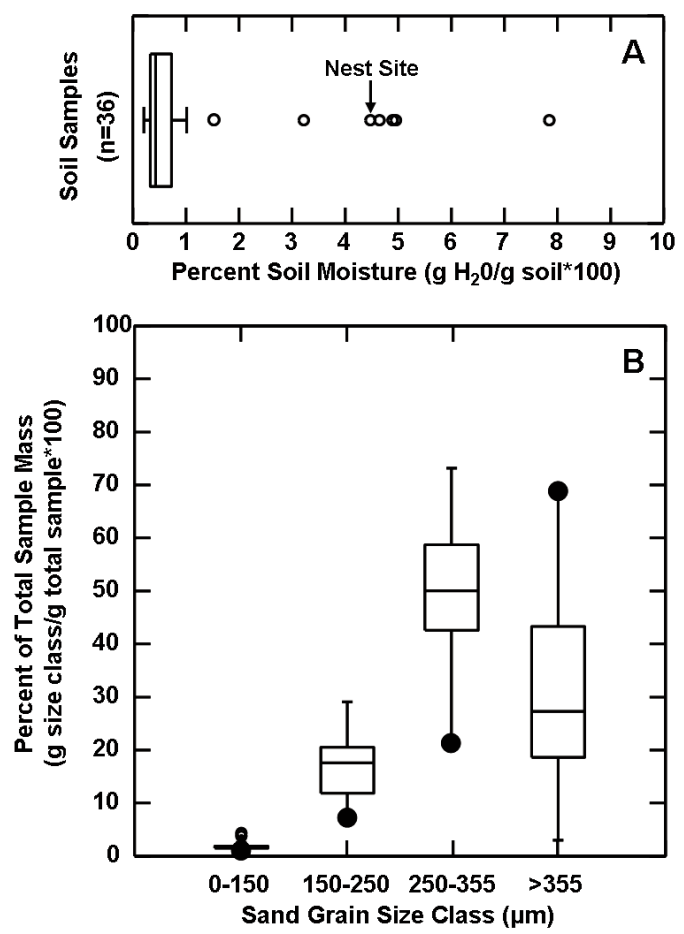

Fig. 1. Soil characteristics of Shinnery oak sand dune habitat available to Sceloporus arenicolus. (A) Box plot of percent soil moisture for all 36 soil samples, including the nest site (arrow; outlier). Whiskers represent the lowest and highest data points found within 1.5 of the lower and upper quartiles, respectively. (B) Box plots of percentage of sample mass for each sand grain size class. Nest location values are shown with solid black dots. Whiskers represent the maximum and minimum values recorded.

$1.2 \%$. Soil moisture at the nest site was $4.5 \%$ (Fig. 1A), the fifth highest moisture percentage recorded across the entire study site. On average, percent of total sample mass for each sand grain size class was $1.2 \%$ for $0-150 \mu \mathrm{m}$, $17.0 \%$ for $150-250 \mu \mathrm{m}, 50.1 \%$ for $250-355$ $\mu \mathrm{m}$, and $30.1 \%$ for $>355 \mu \mathrm{m}$. For the nest site, percent of total sample mass for each sand grain size class was $0.5 \%$ for $0-150 \mu \mathrm{m}, 8.0 \%$ for $150-250 \mu \mathrm{m}, 21.7 \%$ for $250-355 \mu \mathrm{m}$, and $68.2 \%$ for $>355 \mu \mathrm{m}$. These nest site values represent the highest recorded value in the data set for the $>355 \mu \mathrm{m}$ size class, the lowest recorded value for 250-355 $\mu \mathrm{m}$ and 150-250 $\mu \mathrm{m}$ size classes, and the third lowest recorded value for 50.1 for the $0-150 \mu \mathrm{m}$ size class (Fig. 1B). Although many other unmeasured environmental parameters are likely important in nest site selection (e.g., soil compaction), these data suggest that the $S$. arenicolus female se- lected a nest site based on soil moisture content and sand grain size distribution relative to conditions available in the surrounding area. The nest chamber location was wetter than most other locations sampled, and sand at the surface above the chamber was composed mostly of large sand grains $(>355 \mu \mathrm{m})$ and relatively few small sand grains $(<355 \mu \mathrm{m})$.

Assuming that energy is limited, a given reproductive effort can be expended by the production of either a few large offspring or many small ones (Stearns 1992). The clutch sizes described here match the lowest reported for the species (3; Degenhardt et al. 1996, Fitzgerald and Painter 2009), and the one hatchling recovered from those nests, which produced the first hatchling size reported for this species, was $1 \mathrm{~mm}$ larger than the maximum reported for a closely related species, S. graciosus (27 mm; Smith 1995). Though small, this data set can begin to shape several working hypotheses for why clutch sizes were small and invariant in this population of lizards (Dunham et al. 1988a). One hypothesis is that aspects of the available habitat directly constrained, via resource limitation (e.g., drought; Trauth 1983, Haenel 2011), the number of eggs produced by the female. An alternative hypothesis is based on the egg-size versus egg-number trade-off. That is, natural selection may have favored a strategy of energy allocation to smaller clutch sizes with larger hatchlings because this strategy maximizes lifetime reproductive success (Jordan and Snell 2002). Another alternative hypothesis is that predation risk might constrain the morphology of gravid females to a form that allows fewer eggs but greater performance (e.g., escape ability; Schwarzkopf 1994). While the limited size of this data set precludes the rejection of any of the hypotheses above, there is some evidence suggesting that gravid $S$. arenicolus females in this population experience a high rate of predation. Five of the 20 gravid females tracked in the radiotelemetry study described above were lost to snake predation (4 taken by Masticophis flagellum and 1 taken by an unknown snake). To begin distinguishing among these and other potential hypotheses of reproductive life history evolution, future work should focus on life history studies at multiple sites throughout the range of $S$. arenicolus.

Taken together, these observations represent a first step toward characterizing the 
reproductive and nesting ecology of $S$. arenicolus. Thorough understanding of life history variation in $S$. arenicolus would contribute greatly to a working model of life history evolution for this lizard and also provide a better understanding of the contributions of egg and hatchling survival to the dynamics of $S$. arenicolus populations.

We thank the Bureau of Land Management for funding the soil survey and other research on S. arenicolus, and the New Mexico Department of Game and Fish for funding the radiotelemetry research. We also thank C. Painter, T. Cotten, H. Boostrum, R. Jennings, D. Hill, C. Gilman, S. Bird, T. Allen, and Q. Northrip for assistance in the field. We would also like to thank T. Hibbitts, D. Leavitt, J. Huntley, M. Sears, and D. Miles for helpful discussions of this manuscript. This is contribution 1438 of the Biodiversity Research and Teaching Collection.

\section{Literature Cited}

Angilletta, M.J., Jr., M.W. Sears, and R.M. Pringle. 2009. Spatial dynamics of nesting behavior: lizards shift microhabitats to construct nests with beneficial thermal properties. Ecology 90:2933-2939.

Carter, M.R. 1993. Soil sampling and methods of analysis. Lewis Publishers, Boca Raton, FL.

CoLE, C.J. 1975. Karyotype and systematic status of the sand dune lizard (Sceloporus graciosus arenicolous) of the American Southwest. Herpetologica 31:288-293.

Degenhardt, W.G., and K.L. Jones. 1972. A new sagebrush lizard, Sceloporus graciosus, from New Mexico and Texas. Herpetologica 3:212-217.

Degenhardt, W.G., C.W. Painter, and A.H. Price. 1996. Amphibians and reptiles of New Mexico. University of New Mexico Press, Albuquerque, NM.

Dunham, A.E., B.W. Grant, and K.L. Overall. 1989. Interfaces between biophysical and physiological ecology and the population ecology of terrestrial vertebrate ectotherms. Physiological Zoology 62:335-355.

Dunham, A.E., D.B. Miles, and D.N. Reznick. 1988a. Life history patterns in squamate reptiles. Pages 441-552 in C. Gans and R.B. Huey, editors, Biology of the Reptilia. Volume 16, Ecology B, Defense and life history. A.R. Liss, NY.

Dunham, A.E., P.J. Morin, And H.M. Wilbur. 1988b. Methods for the study of reptile populations. Pages 331-386 in C. Gans and R.B. Huey, editors, Biology of the Reptilia. Volume 16, Ecology B, Defense and life history. A.R. Liss, NY.

FitzGERALD, L.A. 1994. The interplay between life history and environmental stochasticity: implications for management of exploited lizard populations. American Zoologist 34:371-381.

Fitzgerald, L.A., And C.W. PainTer. 2009. Dunes sagebrush lizard (Sceloporus arenicolus). Pages 128-201 in L.L.C. Jones and R.E. Lovich, editors, Lizards of the American Southwest. Rio Nuevo Publishers, Tucson, AZ.

FoLK, R.L. 1980. Petrology of sedimentary rocks. Hemphill Publishing Company, Austin, TX.

HAEnEL, G. 2011. Effects of habitat on clutch size of ornate tree lizards, Urosaurus ornatus. Western North American Naturalist 71:247-256.

Jordan, M.A., AND H.L. SNELL. 2002. Life history tradeoffs and phenotypic plasticity in the reproduction of Galápagos lava lizards (Microlophus delanonis). Oecologia 130:44-52.

Laurencio, L.R., AND L.A. FitzGerald. 2010. Atlas of distribution and habitat of the dunes sagebrush lizard (Sceloporus arenicolus) in New Mexico. Texas Cooperative Wildlife Collection, Department of Wildlife and Fisheries Sciences, Texas A\&M University, College Station, TX. ISBN\# 978-0-615-40937-5.

OveralL, K.L. 1994. Lizard egg environments. Pages 51-72 in L.J. Vitt and E.R. Pianka, editors, Lizard ecology. Princeton University Press, Princeton, NJ.

SABath, M. 1960. Sceloporus g. graciosus in southern New Mexico and Texas. Herpetologica 16:22.

SCHWARZKOPF, L. 1994. Measuring trade-offs: a review of studies of costs of reproduction in lizards. Pages 7-32 in L.J. Vitt and E.R. Pianka, editors, Lizard ecology. Princeton University Press, Princeton, NJ.

SмiтH, H.M. 1995. Handbook of lizards. Comstock Publishing Company, Inc., New York, NY.

Smolensky, N.L., AND L.A. FitzGerald. 2010. Distance sampling underestimates population densities of dunedwelling lizards. Journal of Herpetology 44:372-381. 2011. Population variation in dune-dwelling lizards in response to patch size, patch quality, and oil and gas development. Southwestern Naturalist 56:315-324.

Stearns, S.C. 1992. The evolution of life histories. Oxford University Press, Oxford.

Tracy, C.R., AND H.L. SNELL. 1985. Interrelations among water and energy relations of reptilian eggs, embryos, and hatchlings. American Zoologist 25:999-1008.

Trauth, S.E. 1983. Nesting habitat and reproductive characteristics of the lizard Cnemidophorus sexlineatus (Lacertilia: Teiidae). American Midland Naturalist 109:289-299.

Received 6 March 2012 Accepted 28 July 2012 